A Journal of Culture, English Language, Teaching \& Literature ISSN 1414-3320 (Print), ISSN 2502-4914 (Online)

$$
\text { Vol. } 18 \text { No.1; July } 2018
$$

Copyright (C) Soegijapranata Catholic University, Indonesia

Deviation of Meanings with Homonymy as an Effort to Build Humor in Meme: A Semantic Study

${ }^{1}$ Mochamad Ighfir Sukardi, ${ }^{2}$ Sumarlam, and ${ }^{3}$ Sri Marmanto

1,2,3 Descriptive Linguistics Program, Graduate School, Sebelas Maret University, Surakarta, Indonesia

email: 1'mochamadighfir@gmail.com, ${ }^{2}$ sumarlamwd@gmail.com, ${ }^{3}$ marmanto@staff.uns.ac.id 


\title{
Deviation of Meanings with Homonymy as an Effort to Build Humor in Meme: A Semantic Study
}

\author{
${ }^{1}$ Mochamad Ighfir Sukardi, ${ }^{2}$ Sumarlam, and ${ }^{3}$ Sri Marmanto \\ 1'mochamadighfir@gmail.com, ${ }^{2}$ sumarlamwd@gmail.com, \\ ${ }^{3}$ marmanto@staff.uns.ac.id \\ 1.2.3 Descriptive Linguistics Program, Graduate School, Sebelas \\ Maret University, Surakarta, Indonesia
}

\begin{abstract}
The purpose of this study is (1) Describe how the use of homonymy for deviation of meaning as an effort to build humor in meme. (2) Describes a pattern of deviations of meaning that utilize homonymy in memes. This research is a descriptive-qualitative research. The data were collected using the method of simak and technique of notes. Data analysis in this research use method of match referential and connecting techniques to support codification, reduction, display, and interpretation in accordance with qualitative research framework. The results of this research, found the use of relations of homonymous meaning include the word base, derivative, foreign, and slang. Also found a deviation of meaning by utilizing homonymy that occurs due to euphemism, naming, and awarding pause. In addition to homonymy also found the use of homophony and then homography of word abbreviation. There are three patterns used to make deviations of meaning by utilizing homonymy. (1) The abused word is accompanied by text as explanatory. (2) The abused word is accompanied by the picture as explanatory. (3) The abused word does not appear in the language symbol but the image with the text as explanatory. The holder of the important role of deviation of meaning in the meme is the image and the use of collocation. The right collocation is capable of tricking the reader before finally being startled by a second meaning. Collocation can determine the successful use of homonymy to build humor in a meme. If the meaning of collocation fails to deliver the reader to the meaning presented, then the meaning of the surprise fails to show.
\end{abstract}

Key words: deviations of meaning, homonymy, humor, meme 
132 Celt: A Journal of Culture, English Language Teaching \& Literature, Volume 18, Number 1, July 2018, pp. 131 - 148

Abstrak: Tujuan dari penelitian ini adalah (1) mendeskripsikan bagaimana penggunaan homonimi untuk penyimpangan makna sebagai upaya membangun humor dalam meme. (2) mendeskripsikan pola penyimpangan makna yang memanfaatkan homonimi dalam meme. Penelitian ini termasuk penelitian deskriptif kualitatif. Data-data dikumpulkan menggunakan metode simak dengan teknik lanjutan catat. Analisis data pada penelitian ini menggunakan metode padan referensial dengan teknik hubung banding untuk mendukung kodifikasi, reduksi, penyajian, dan intepretasi sesuai dengan kerangka kerja penelitian kualitatif. Hasil dari penelitian ini, ditemukan penggunaan relasi makna homonimi meliputi kata dasar, bentukan, asing, dan slang. Ditemukan juga penyimpangan makna dengan memanfaatkan homonimi yang terjadi karena eufemisme, penamaan, dan pemberian jeda. Selain homonimi ditemukan juga pemanfaatan homofoni dan homografi singkatan kata. Ada tiga pola yang digunakan untuk melakukan penyimpangan makna dengan memanfaatkan homonimi. 1) Kata yang disimpangkan didampingi dengan teks sebagai penjelas. 2) Kata yang disimpangkan didampingi dengan gambar sebagai penjelas. 3) Kata yang disimpangkan tidak muncul dalam simbol bahasa melainkan gambar dengan teks sebagai penjelas. Pemegang peran penting penyimpangan makna dalam meme adalah gambar dan penggunaan kolokasi. Kolokasi yang tepat mampu mengelabuhi pembaca sebelum akhirnya dikejutkan oleh makna kedua. Kolokasi bisa menentukan keberhasilan pemanfaatan homonimi untuk membangun sebuah humor dalam meme. Saat makna kolokasi gagal mengantarkan pembaca pada makna yang disajikan, maka makna kejutan gagal untuk dihadirkan.

Kata kunci: penyimpangan makna, homonimi, humor, meme

\section{INTRODUCTION}

Meme is defined as an idea, thought, habit or style that spread from person to person in a culture (Diaz, 2013, p. 84). Furthermore, Buchel (2012, p. 29) explains memes are writings that are often accompanied by certain images, photographs, and characters. Memes tend to have an element of humor or satire on a social and political issue.

The development of the means of communication leads us to a change of style in reveal something. One of the new tools in reveals something is meme. Memes become very popular in the virtual world because of its ability to pack information, messages, ideas, thoughts, criticism, and even humor in a brief and dense. 
Humor is a spontaneous stimulus that provokes a smile and a person's laughter. Humor can be both verbal and nonverbal (Wijana, 2003, p. 3). In memes, nonverbal humor is usually a funny picture or photo, whereas verbal humor is short text or a short dialogue. Humor grows in all walks of life and evolves over time. According to Wijana (2003, p. 3) humor can free human self from the burden of anxiety, confusion, cruelty, and misery. Humor becomes one of the things that people are so fond of. Unconsciously, humor is always close to the community and become part of society.

Practical consumption demands make the meme with humor should use short and simple text, but contain absurd logic that tempts the connoisseur to think. Humor in a meme has a different point of cuteness. There is a meme whose point of humor is be in the cohesiveness image and text. In this case if the picture or text appears alone can not produce humor, because the point of funny this meme be in the relationship of images and text. Some memes have a point of funny on the picture. Text in such memes only serves as an addition. In the sense that the picture has been able to stimulate the audience to laugh even without the presence of the text. Last is the meme with the humor on the text, the picture position is just as an extra. The humor in this meme uses the language aspect as an important capital to build cuteness.

Most research on humor has been based on psychological theory that pivots on the concept of incongruity, conflict, and relief (Wijana, 2003, p. 5). Something abnormal on at one time can cause humor and at other times can be not funny. Things that are considered funny by certain societies can be not funny for other societies (Pradopo, Maharto, \& Hariyono, 1987, p. 5). Verbal behavior that is considered funny usually depends on several things. First, the sounds of the words chosen, the meaning of the words, the veiled meanings, and even the contrast or misappropriation of a rule, custom or culture (Suhadi, 1989).

Relationship between meanings is called relation of meaning. The relation of meaning is the semantic relationship held between the lingual unit one with the other lingual.The lingual unit in question can be a word, phrase, or sentence. While semantic relation can be interpreted as the similarity of meaning, the contradiction of meaning, the inclusiveness of meaning, the multiplication of meaning or also the advantages of meaning. Such relations are often also referred to as synonyms, antonyms, polysemics, homonyms, hyponim, and ambiguity (Parera, 2004; Leech, 2003; Ullmann, 2012). 
134 Celt: A Journal of Culture, English Language Teaching \& Literature, Volume 18, Number 1, July 2018, pp. 131 - 148

The relationship that will be discussed more deeply and become a reference in this research is the relation of ambiguity of meaning, especially homonym. Ambiguity of meaning or meaninglessness is defined as a state in which there are two or more meanings in different contexts (Ullmann, 2012). Actually, the emergence of ambiguity of meaning becomes a separate problem in conducting a conversation. Nevertheless, in the world of poetry, obscurity and coercion of new meanings are used to enrich the ideas conveyed by a poet (Aminudin, 2003, p. 19). Whereas in humor lexical ambiguity is used as a capital to build humor by distorting meanings.

This study focuses on memes that utilize homonymy to distort meaning. According to Ulman (2012) every word has the potential to have more than one meaning. The meaning of a word can refer to something different according to its usage environment. One of the manka relations that belongs to this type of lexical ambiguity is homonymy (Ulman, 2012). Departing from the description, this study will hold on to homonymous theory to study the deviation of meaning as an effort to build humor in meme.

\section{LITERATURE REVIEW}

\section{A. Deviation of meaning}

The two main concepts in humor are incongruity and resolution (Attardo, 1997, p. 395). The concept explains that a humor can be felt humorous if the reader or listener of a humor can feel the incongruity or weirdness that is in humor. Then the incongruity will be resolved by connecting it to the hidden meaning of the word game. However, this did not rule out the incongruity that will be ignored without resolution.

Based on the joke making techniques, there are two techniques for making humor that are techniques of metaphor usage and symbolization techniques. The technique of using metaphors is an attempt to attract the attention of the listener or reader and encourage a new interpretation. While the technique of symbolization is how to insert or imply a second meaning based on the first meaning. The two meanings of words in humor should be at different levels (clause or sentence context) (Attardo, 1997, p. 395).

The first meaning is the obvious meaning of 'the meaning that is presented'. Second is the meaning of 'new' that overlapping with the first meaning that will appear when re-interpretation or also called 'meaning of 
surprise' (Husen, 2001, p. 356-357). Humor can cause laughter when it is something that is which is strange, wrong, or defective. Our events or experiences of the world conveyed through humor are strange, odd, and distorted object. In addition, to cause laughter humor must suddenly awaken us to the mismatch between the concept with the real reality (Husen, 2001, p. 357). Humor arises from finding unexpected things from being delivered. Sentences that give rise to two kinds of associations. First called the unexpected turns technique and the second is double association (Husen, 2001, p. 35).

\section{B. Homonymy}

Homonimi comes from the Latin word "homo" meaning the same and "nomos" means name. Homonymy are two or more lexem of the same shape and sound, but have different meanings (Subroto, 2011, p. 81). Example: between the word "bisa I" which means 'poison' and the word "bisa II" which means 'able'; between the word "mengurus" which means 'Interfere with people' and the word "mengurus" which means 'become thin'. Pateda (2010, p. 211) explains that homonymy is the same name for different things. Further Parera (2004, p. 81) explains that homonynames are two utterances in the form of the same word pronunciation or the same spelling or writing.

The words "bisa I" and "bisa II" are two different lexem, so their morphological and semantic behavior is also different. Lexem "bisa I" can be morphologically formed into: "berbisa" which mean 'venomous', while syntactically can join with other nouns ("bisa ular" which mean poison of snake). Both words also have different word classes, this happens because the two words are uptake from another language. "bisa I" is an uptake word from Malay which means poison and "bisa II" is the uptake from the Java language which means able.

The polysemy difference with homonym, homonym is not a word (of the same lexeme) which has several meanings, but two or more words of the same form. Of course, since this homonym is not from the same word, the meaning is different. Therefore, the word homonymized is listed as different entries in the dictionary (Leech, 2003). Conversely, the word polysemy is a word that has more than one meaning. This polysemic originates from the same lexeme and in the dictionary is listed as a single entry.

There is another difference between homonymy and polysemy, the meaning of word homonymy has no connection or relationship at all between 
136 Celt: A Journal of Culture, English Language Teaching \& Literature, Volume 18, Number 1, July 2018, pp. 131 - 148

one another (Leech, 2003). The meaning of the word polysemy is still related because it is developed from the components of the meaning of the word itself.

The descriptions may have confirmed the polysemic differences with homonym. However, the difficulties faced by the linguists are not just to distinguish the lexemes alone. Experts find it difficult to trace the historical traces of a word. Given the concept of polysemy always question whether the ambiguity of meaning comes from the same word. Furthermore, polysemics also demand to know the relation of meaning from the meanings that arise. As Leech (2003) declared that polysemic should be viewed historically and psychologically. What if two meanings are derived from the same word historically, but we can not psychologically decipher the relation of meaning between them, because the relation of meaning can only be understood by the speakers of the language of on a given time.

From that opinion, it should be emphasized the pedestal of homonymy in this study. When the relationship of meaning from a word is hard to find then it includes homonymy. Although historically the origin of the word may well prove to be polysemic. However, the purpose of this study not to trace the origin of a word to ascertain polysemy or homonym. The determinant of a polysemic or homonymous word in this study is the context surrounding the word used in a meme.

Homography are two or more lexem of the same writing and different pronunciations, have different lexical meanings, including in different lexemes. An example of the word homography is "apel I" and "apel II", "apel I" is pronounced [apEl] (E: read e pepet), while "apel II" is pronounced [apel] (Subroto, 2011, p. 84). Lexem "apel I" is included in the noun (the type of round fruit and often eaten by humans) and the apple's own referent. Lexem 'apel II' includes verbs and the lexical meaning is a neatly marching action in groups (for TNI, police, security guards, and the like).

Homophones are two lexem or more who have the utterance of same, but the written form is different. Homophones have different lexical meanings, including in different lexemes. An example of a homophonic word is "bang" and "bank". Both words have the same utterances, the writings are different, the meanings are different so they enter in different lexemes. The word "bang" means (brother) including a greeting or word to greet someone, while "bank" means (the institution that deals with the traffic of money) including the noun. As described earlier, each different lexeme is likely to exhibit different morphological and syntactic behaviors (Subroto, 2011, p. 85). 


\section{METHODOLOGY}

Some of the things that are key in research methods, namely the scientific way, data, purpose, and usability. Research methods are needed in achieving research objectives because the methods that formulate ideas and thoughts are based on a scientific approach. The method used in this research is descriptive qualitative method. This is because the data analyzed is not in the form of numbers, symbols or coefficients about inter-variable relationships. Qualitative method as a research procedure that produces descriptive data in the form of written or oral words of the people and behavior that can be observed. This approach is directed to the background and the individual holistically (Sugiyono, 2014; Aminudin, 1990; Moleong, 2013).

Data and sources of data in this study are determined based on the needs in the research problem. The data in this research is a meme text that contains deviations of meaning by utilizing homonym. Sources of data in this study are memes taken from Meme Comic Indonesia web (MCI), accessible at www.memecomic.id. Data is taken within 4 months, starting from January to April 2017. The data were collected using the method of simak and technique of notes.

The use of the method of simak and technique of notes in the provision of data is not a separate process (Mahsun, 2014). Further the data analysis in this research use method of match refrential and techniques to support codification (Mahsun, 2014). It compares deviations of meaning with the referent to support codification, data reduction, data display, and interpretation in accordance with the qualitative research framework (Sugiono, 2014).

\section{RESULTS AND DISCUSSION}

\section{A. Homonym}

1. Homonym basic word

The deviation of meaning by utilizing the basic word homonyms can be observed in some of the data shown below.

a) Kenapa kamu diam saja? padahal kamu tahu. (dengan gambar tahu sebagai penjelas). Jan/17.G 
138 Celt: A Journal of Culture, English Language Teaching \& Literature, Volume 18, Number 1, July 2018, pp. 131 - 148

Why are you silent? but you know. (with picture "Tahu" as explanatory).

b) Hemat pangkal kaya. Rajin pangkal pintar. Enak pangkal paha. $\operatorname{Mar} / 7 . T$

Thrifty base of the rich. Diligent base of smart. Delicious base of the thigh (Favors groin).

c) Mengandung unsur pornografi, angin puting beliung disensor KPI (dengan gambar sensor sebagai penjelas). Feb/26.G

Contains elements of pornography, KPI censored tornado winds (the wind of pickaxe nipple). (With the picture of sensor as explanation).

In the data (a) the text appears in the form of questions ending in clarification. The meaning of collocation presented by the text requires that the word "tahu" contains the meaning of 'understand'. However, there is a distortion of the meaning of the word "tahu" by presenting the picture of food "tahu" which is in the same linguistic form. Utilization of homonymy on data (a) deviate of meaning implies irrationality or absurdity in the experience conveyed through language.

The strangeness is a testament to the effort to build humor in the meme. At (b) there is the word "pangkal" three times, but the word "pangkal" that last experience a deviation of meaning. "Hemat pangkal kaya. Rajin pangkal pintar." is a proverb that the word "pangkal" in the saying has the meaning of 'beginning or base'. While the word "pangkal" on "enak pangkal paha" has the meaning of 'favors the groin'. In addition to utilizing homonymy of data (b) also utilize something taboo to build humor. Last data (c) utilizes the homonym "puting" to deviate meaning. "Puting" has the meaning of 'base or besic' and there is also the word "puting" with the meaning of 'nipple or clitoris'. The humor in the data (c) is built by utilizing the deviation of meaning and the discussion of something taboo.

\section{Homonym derivative}

The deviation of meaning by utilizing the derivative homonyms can be observed in some of the data shown below. 
d) Uda kayak martabak manis aja dikacangin terus (dengan gambar martabak sebagai penjelas). Apr/15.G

Like a sweet martabak given peanuts (with martabak pictures as explaners)

e) Jangan bangga jadi atasan. Karena dipasar atasan 10 ribu dapat 3 kalau lagi obral bisa 5. Jan/9.T

Do not be proud to be a boss. Because in the upper clothing market the price is cheap.

In the data (d) deviations of meaning make use of the homonym of the derivation "di-kacang-in" with the meaning of 'given or sprinkled with nuts'. The word "dikacangin" in the text refers to the meaning 'ignored'. The text in the data (d) uses a martabak image sprinkled with nuts to explain its deviation. Last data (e) begins with a suggestion not to be proud to be a "atasan" (boss). The text presents the word "bangga" (proud) in an attempt tolock the interpretation of the meaning of the reader to the word "atasan" (boss). Thus the reader will interpret the word "atasan" with 'leader or boss'. Furthermore, the text suddenly distorts the meaning of "atasan" with reference to 'upper lingerie of women'. The deviation of meaning done in memes brings irrationality or absurdity in the experience conveyed through language. It is an attempt to build humor in a meme.

3. Homonym foreign of word

The deviation of meaning by utilizing the homonymous foreign of word can be observed from of the data shown below.

f) Katanya diskon all item, tapi barangnya ga da yang item. Apr $/ 2 . T$

He said discount all items, but the goods are not black.

Data (f) begins with information on the existence of discounts all item. Then ends with a deviation of the meaning of the word "item" in English which means 'goods'. In the Indonesian language the word "item" means 'black'. The deviation of meaning occurs in data (f) presents an error in understanding. It happens as an effort to build humor in the meme. 
140 Celt: A Journal of Culture, English Language Teaching \& Literature, Volume 18, Number 1, July 2018, pp. 131 - 148

4. Homonym word of slang

The deviation of meaning by utilizing the homonymous word of slang can be observed from of the data shown below.

g) Ngelem sepatu yg rusak karna nanti mau dipakai. Eh.. malah ngefly tu sepatu. Mar/18.T

Gluing shoes that are broken because it will be using that. Eh.. the shoes were drunk.

In the data (g) deviation of meaning utilizing homonymous word "ngelem" with the meaning of 'gluing using glue'. However, the word "ngelem" in the data (g) its meaning is distorted to 'drunk using glue'. The word "ngelem" is a new word that comes after many cases of hangovers using glue. Data $(\mathrm{g})$ uses homonymy to distort meaning by generating the word "ngefly" (drunk) as an explanation of the existing deviation. The deviation of meaning that occurs in the data $(\mathrm{g})$ seeks to surprise the reader with the second meaning raised. This is done as an effort to build humor in meme.

5. Homonyms happened because euphemism

The deviation of meaning by utilizing the homonymous that happened because euphemism can be observed from of the data shown below.

h) Mengusir burung. Mengundang burung. (Data dalam meme ini membandingkan gambar orang-orangan sawah yang diberi teks "mengusir burung" dengan gabar wanita seksi yang diberi teks "mengundang burung"). Feb/11.G

Repel birds. Inviting birds.the data in this meme compares the scarecrow's picture with the text "mengusir burung" (casting out birds) with sexy women who were texted "mengundang burung" (inviting birds).

In the data (h) deviations of meaning take advantage of homonimi the word "burung" with the meaning of 'two-legged animals, winged, hairy, and usually able to fly'. However, the word "burung" in data (h) experiences a deviation of meaning became 'male genitalia'. Data (h) uses homonymy to distort the meaning of words by comparing images capable of make the word of "burung" different meanings. The deviation of 
meaning that occurs in the data $(\mathrm{h})$ attempts to present a much different comparison.

The picture in the meme serves to support the comparison and explains the location of the deviation of its meaning. This is done as an effort to build humor in meme.

\section{Homonyms happened because naming}

The deviation of meaning by utilizing the homonymous that happened because naming can be observed from of the data shown below.

i) Jangan membalas budi, karena belum tentu Budi melakukannya. Jan $/ 28 . T$

Do not returning the favor, because not necessarily Budi do it.

In the data (i) begins with the prohibition to repay the favor. This prohibition presents discrimination to the reader, for "mem-balas budi" (repayment) is norms that exist in society. Furthermore the data (i) suddenly distorts the meaning of "budi" by reference 'goodness or service' to be came 'person's name'. Data (i) uses homonymy that occurs because of personalized naming to distort meaning. The deviation of meaning that occurs in this data brings irrationality or absurdity in the experience conveyed through language. This is done as an effort to build humor in meme.

\section{Homonyms happened because of giving pause}

The deviation of meaning by utilizing the homonymous that happened because giving pause can be observed from of the data shown below.

j) Awas korban KB merajalela. Berhati-hatilah dengan KB. Keluar ga Berencana. Mar/4.T

Watch out for $\mathrm{KB}$ victims rampant. Be careful with $\mathrm{KB}$. Exit is not planned. In the data (j) "KB" is the abbreviation of the word of the family planning. In this data a deviation of meaning utilizes homonymy that occurs due to the giving of pauses in a word. The word "keluarga" of a lexeme with the meaning of 'family or relatives' turns into two lexemes because the giving of pauses of "keluar" means 'exit' and "ga" meaning 'no' (including slang). This distinction results in distorting the meaning of the extension "KB" that is already known by the public. The deviation of 
142 Celt: A Journal of Culture, English Language Teaching \& Literature, Volume 18, Number 1, July 2018, pp. 131 - 148

meaning that occurs in the data $(\mathrm{j})$ makes "KB" which originally had a positive impression to be negative. This is done as an effort to build humor in meme.

8. Homography the abbreviation of word

The deviation of meaning by utilizing the homography abbreviation of word can be observed from of the data shown below.

k) Udah cantik, jago $M L$. (dengan gambar gadis cantik yang sedang bermain game ML). April/30.G

Besides beautiful also ML experts. (With a picture of a beautiful girl playing ML game).

In the data $(\mathrm{k})$ deviation of meaning utilizing homography of word abbreviation "ML" that meaning 'Making Love'. However, the abbreviation of the word "ML" in the data $(\mathrm{k})$ suffers irregularities into 'Mobile Legend'. "Mobile Legend" is an online game that is in favor of smartphone users. Data $(\mathrm{k})$ uses a homography to distort the meaning of a word abbreviation by displaying a picture of a beautiful girl playing Mobile Legend as a descriptor of the abbreviation of the word "ML". The deviation of meaning that occurs in the data $(\mathrm{k})$ seeks to attract the reader's attention. "ML" in the data $(\mathrm{k})$ has a poor impression when observed from the meme context and the meaning of collocation presented. The picture in the meme serves to surprise the reader with the second meaning raised. This is done as an effort to build humor in meme.

\section{Homophones}

The deviation of meaning by utilizing the homophones can be observed from of the data shown below.

1) Sebenarnya yang melahirkan uang adalah Mpok Indonesia. Bank Indonesia Cuma bisa menanam benih. Feb/12.T

Actually, who gave birth to money is Mpok Indonesian. Bank of Indonesian can only plant seeds. (Mpok is a call for sister and Bang is call for brother).

In the data (l) the text begins with a claim to a fact different from that known in general. Claims against the facts at the beginning will make the 
reader think because of the awkwardness presented. Furthermore, the text provides a resolution by presenting a deviation of meaning to the word "bank". This deviation of meaning utilizes the homophone of sound similarity from the words "bank" and "bang". The deviation of meaning is explained by text which presents the word "mpok".

\section{B. Patterns deviations of meaning in memes}

1. Patterns deviations of meaning with text as explanation

Deviation of meaning with homonymy is found with a pattern of presentation of the first meaning is clearly visible. Furthermore, the meaning of surprise is brought to disrupt the first meaning presented. The presentation of the first meaning is supported by appropriate collocation so that the meaning presented is accepted by the reader. The right collocation will make a word that is not consciously consonant with its consonant. After the meaning presented is accepted by the reader, then the meaning of surprise is presented to end the text. The right collocation will create a word that the homonym does not realize as a homonym. After the meaning presented is accepted by the reader, then the meaning of surprise is presented to end the text. This pattern can fool the reader and make the reader think. Then the reader of shock with the weirdness presented to stimulate the laughter of the reader.

m) Jangan suka ngurusi orang lain, karena belum tentu orang itu ingin kurus. Feb/3.T

Dont like to interfere with the lives of others, because not necessarily the person wants to be skinny.

Data $(\mathrm{m})$ shows how a pattern of deviations of meaning with homonym was created. Collocation plays a very important role to give a second surprise and meaning to the reader. Without the proper collocation the word "ngurusi" can fail in presenting the meaning of the target and the meaning of surprise ("ngurusi" can mean 'interfere people life' and 'make a thin').

2. Patterns deviations of meaning with picture as explanation

Deviation of meaning with homonymy is also found with the pattern of text relations and pictures. The meaning to be distorted is presented in the text. The picture serves to explain where the deviation of its meaning. 
144 Celt: A Journal of Culture, English Language Teaching \& Literature, Volume 18, Number 1, July 2018, pp. 131 - 148

In this pattern, there are two things that are used to present the first meaning. First, the proper use of collocation (as described earlier). The second is utilizing the word's closeness with the community. When a homonymous word appears without a context, the society tends to interpret the word and rule out that it is a homonym. This is what the word proximity means to society. When one of the meanings of a homonymous word is used more frequently in society, other meanings will be ignored. If the word appears without context and other words, then people will use a meaning that is closer to them.

n) Pencitraan (dengan gambar seorang wanita yang sedang menggunakan produk kecantikan 'Citra') Mar/23.G

Imagery (with the picture of a woman who is using 'Citra' beauty products)

Data ( $\mathrm{n}$ ) shows the use of the picture as an explanation of the distorted meanings. When the word "pencitraan" is displayed on its own without any other words, "pencitraan" will tend to be interpreted as 'imagery'. This happens considering the political issues that develop in Indonesia is very close to "pencitraan" with the meaning of 'image building efforts'. The function of the picture in the data ( $n$ ) to explain and shock the reader by presenting the second meaning of "pencitraan". The word "pencitraan" refers to 'using Citra beauty products'.

3. Patterns picture as targets and text as explanation

The pattern of deviation with homonyms exists that using the picture as a distorted target. So the word that homonym does not appear in the form of language, but appears in the form of picture. The text that appears serves as an explanation of deviations of meaning.

o) Biasanya ada di toples. Ada jg yg di leher. (dengan gambar ikan cupang) $\operatorname{Mar} / 10 . G$

Usually there in the jar. There is also a neck. (With picture of betta fish).

Data (o) shows the use of the image pattern as the target of the deviation and the text appears as an explanation. The homonymous word in this data is "cupang". The word is not shown with the language code or symbol, but with the picture. In the first data (o) the "cupang" refers to the 
'fish name (betta fish)', while the second "cupang" refers to a 'hickey or the mark red bite'.

\section{Deviation of homonym meaning in meme}

Deviation of meaning by utilizing the relation of homonymous meaning includes the basic word, derivative, foreign, and slang. Also found a deviation of meaning by utilizing homonyms that occur due to euphemism, naming, and giving pause. In addition to homonyms was also found the use of homophones and homographs of the word abbreviation. There are three patterns used to make deviations of meaning by utilizing homonyms. First, a word being abuse is accompanied by a text as explanatory. Second, the word being abused accompanied by the picture as explanatory. Third, the word being abused does not appear in the language symbol but the picture with the text as explanatory.

The holder of the important role of deviation of meaning in the meme is the picture and the use of collocation. The right collocation can fool the reader before finally being struck by a second meaning. Collocation can determine the successful use of homonyms in building a humor in memes. When the meaning of collocation fails to bring the reader to the meaning presented, the meaning of the surprise fails.

\section{CONCLUSION}

From the research that has been described previously, it has been known how homonyms are used to distort meaning for the purpose of building a humor in memes. Images and collocations hold a very important role in deviating meaning. Utilization of homonyms that include the basic word, derivative, foreign, and slang, and homonyms that occur due to euphemism, naming, and giving pause, and homophonic and homographic of word abbreviations require different patterns of presentation.

The deviations of meaning with homonyms in memes are shown using three patterns: (1) abused word is accompanied by text as explanatory, (2) the word abused is accompanied by the drawing as explanatory, and (3) the word abused do not appear in language symbols but images with text as explanatory. The success of these patterns in establishing humor depends on the accuracy of picture selection and the accuracy of its collocation. 
146 Celt: A Journal of Culture, English Language Teaching \& Literature, Volume 18, Number 1, July 2018, pp. 131 - 148

\section{REFERENCES}

Aminuddin, E. (1990). Pengembangan Penelitian Kualitatif dalam Bidang Bahasa dan Sastra [The Development of Qualitative Research in the Field of Language and Literature]. Malang: Yayasan Asih Asah Asuh \& HISKI.

Aminudin. (2003). Semantik: Pengantar Studi Tentang Makna [Semantics Introduction to the Study of Meanings]. Bandung: Sinar Baru Algensindo.

Arikunto, S. (1993). Prosedur penelitian Suatu pendekatan Praktek [Research Procedure A Practical approach]. Jakarta: Rineka Cipta.

Ariyanto, J., \& Wijana, I. D. P. (2013). Analisis wacana humor Rons Imawan [Analysis of the Rons Imawan humor discourse] (Doctoral dissertation, Yogyakarta: Universitas Gadjah Mada).

Attardo, S. (1994). Linguistic Theories of Humor: Mouton de Gruyter. Berlin: New York.

Beal, C., \& Mullan, K. (2017). The pragmatics of conversational humour in social visits: French and Australian English. Language $\mathcal{E}$ Communication, $55,24-40$.

Buchel, B. (2012). Internet memes as means of communication (Doctoral dissertation, Masarykova univerzita).

Chaer, A. (1990). Pengantar semantik bahasa Indonesia [Introduction to the semantics of Indonesian]. Rineka Cipta.

Díaz, C., \& Mauricio, C. (2013). Defining and characterizing the concept of Internet Meme. CES Psicología, 6(2), 82-104.

Subroto, E. (2007). Pengantar Metode Penelitian Linguistik Structural [Introduction to Structural Linguistics Research Methods]. Surakarta: UPT Penerbitan dan Pencetakan UNS.

Edi, S. (2011). Pengantar Studi Semantik dan Pragmatik [Introduction to Semantics and Pragmatics Studies]. Surakarta: Cakrawala Media.

Husen, I. S. (2001). Yang lucu dalam lelucon Perancis [The funny things in French jokes]. In R. Hidayat (Ed.), Mentas Ranah Bahasa, Semiotika, dan 
Budaya [The world outside Language, Semiotics, and Culture] (pp. 348379). Yogyakarta: Yayasan Bentang Budaya.

Kirk, J., \& Miller, M. L. (1986). Reliability and validity in qualitative research (Vol. 1). Sage.

Kridalaksana, H. (2001). Kamus Linguistik [Dictionary of Linguistics]. Jakarta: Gramedia Pustaka Utama.

Leech, G. (2003). Semantik [Semantics] (P. Partana, Trans.). Yogyakarta: Pustaka Pelajar.

Mahsun, M. S. (2014). Metode penelitian bahasa: tahapan strategi metode dan tekniknya [Research methods in language learning: Stages of method and technique strategies]. Depok: Raja Grafindo Persada.

Huberman, M., \& Miles, M. B. (1992). Analisis data kualitatif: Buku sumber tentang metode-metode baru [Qualitative data analysis: A sourcebook of new methods]. Jakarta: UIPress.

Moleong, L. (2013). Metodologi penelitian Kualitatif [Qualitative research methodology]. Bandung: PT. Remaja Rosdakarya.

Pateda, M. (2010). Semantik Leksikal [Lexical semantics]. Jakarta: Rineka Cipta.

Parera, J. D. (2004). Teori Semantik [Semantic theory] (Vol. 2, 2 ${ }^{\text {nd }}$ ed.). Jakarta: Erlangga.

Poerdawarminta, W. J. S. (2002). Kamus Besar Bahasa Indonesia [The Great Dictionary of the Indonesian Language]. Jakarta: Balai Pustaka.

Pradopo, S. W., Maharto, S. S., \& Hariyono, R. I. (1987). Humor Dalam Sastra Jawa Modern [Humor in Modern Javanese Literature]. Jakarta: Pusat Pembinaan dan Pengembangan Bahasa.

Santosa, R. (2014). Metode Penelitian Kualitatif Kebahasaan [Qualitative Research Methods in Language] (A Draft Book). Surakarta: Fakultas Sastra dan Seni Rupa UNS.

Soedjatmiko, W. (1992). Aspek Linguistik dan Sosiokultural di dalam Humor [Linguistic and Sociocultural Aspects in Humor]. In B. K. Purwo (Ed.), PELBA 5. Yogyakarta: Kanisius. 
148 Celt: A Journal of Culture, English Language Teaching \& Literature, Volume 18, Number 1, July 2018, pp. 131 - 148

Sugiyono. (2014). Metode Penelitian Kuantitatif, Kualitatif dan $R \quad \mathcal{E} D$ [Quantitative, Qualitative Research and R \& D Methods]. Bandung: Alfabeta.

Suhadi, M. A. (1989). Humor itu serius: pengantar ke ilmu humor [Humor is serious business: an introduction to the science theory of humor]. Pustakakarya Grafikatama.

Suwanto, A. A. S., \& Suhandano, M. A. (2012). Analisis wacana humor verbal bahasa inggris (Studi Kasus pada Serial Komedi Situasi How I Met Your Mother) [Analysis of English verbal humor discourse (Case Study on the Situation Comedy Series How I Met Your Mother)] (Unpublishd doctoral dissertation, Universitas Gadjah Mada).

Tarigan, H.G. (2009). Pengajaran Semantik [Semantics learning]. Bandung: Angkasa.

Ullmann, S. (2012). Pengantar Semantik (Adaptasi Sumarsono) [The Introduction to Semantics]. Yogyakarta: Pustaka Pelajar.

Wijana, I., \& Ramlan, M. (1995). Wacana kartun dalam bahasa Indonesia [Cartoon Discourse in Indonesian Language] (Unpublished doctoral dissertation, Universitas Gadjah Mada).

Wijana, I. D. P. (1994). Pemanfaatan Homonimi di dalam Humor [Utilization of Homonym in Humor]. Humaniora, 1. doi: 10.22146/jh.v0i1.2025.

Wijana, I. D. P., \& Putu, D. (1985). Bahasa Indonesia dalam cerita humor [Indonesian language in humorous stories]. Linguistik Indonesia, (5).

Wijana, I. D. P. (2003). Kartun: studi tentang permainan bahasa [Cartoons: study of language games]. Ombak.

Verhaar, J. W. M. (2012). Asas-Asas Linguistik Umum [The Principles of General Linguistics]. Yogyakarta: UGM Press. 